\title{
An Illustrated Key to the Mandibles of Small Mammals of Eastern Canada
}

\author{
Dominique Fauteux ${ }^{1,4}$, Gilles Lupien ${ }^{2}$, François FabianeK ${ }^{3}$, Jonathan Gagnon ${ }^{1}$, Marion SÉguY ${ }^{1}$, \\ LOUIS IMBEAU ${ }^{1}$
}

${ }^{1}$ Chaire industrielle CRSNG-UQAT-UQAM* en aménagement forestier durable and Centre d'étude de la forêt, Université du Québec en Abitibi-Témiscamingue, Rouyn-Noranda, Québec J9X 5E4 Canada

${ }^{2}$ Ministère du Développement durable, de l'Environnement, de la Faune et des Parcs, Direction régionale du Saguenay-Lac Saint-Jean, Jonquière, Québec G7X 8L6 Canada

${ }^{3}$ Centre d'étude de la forêt, Faculté de foresterie, géographie et géomatique, Université Laval, Québec, Québec G1V 0A6 Canada

${ }^{4}$ Corresponding author: dominique.fauteux.1@ulaval.ca

Fauteux, Dominique, Gilles Lupien, François Fabianek, Jonathan Gagnon, Marion Séguy, and Louis Imbeau. 2014. An illustrated key to the mandibles of small mammals of eastern Canada. Canadian Field-Naturalist 128(1): 25-37.

Skulls are often used to identify small mammals, and most identification keys to small mammals have been developed on the assumption that whole skulls will be available. However, the skulls of small mammals are seldom found intact in predator pellets or nests, and the bones of several individuals are often scattered and mixed, making counting impossible without the use of a specific cranial part. In addition, only a few keys include all the species found in the eastern provinces of Canada.

Mandibles readily resist degradation by the gastric acids of both avian and mammalian predators and are often found intact in food caches of mustelids and in bat hibernacula. We therefore designed an illustrated dichotomous key to small mammals (mean mass $<5 \mathrm{~kg}$ ) of eastern Canada based on diagnostic mandible characters (including the teeth and one dentary bone). We identified and confirmed diagnostic characters to distinguish 55 species from the orders Lagomorpha, Rodentia, Soricomorpha, Carnivora, and Chiroptera. These diagnostic characters are based on a review of the literature and were confirmed by measurements performed on both museum and trapped specimens. In order to facilitate identification, photographic illustrations are provided for each couplet of the key.

The ability to identify small mammals using their mandibles will reduce the number of skull components needed and has proven to be a useful tool in the study of the diet of predators. This key may also be helpful in identifying bats in the genera Myotis, Perimyotis, and Eptesicus, which are presently affected by the spread of white-nose syndrome (caused by Pseudogymnoascus destructans) throughout the eastern part of Canada.

Key Words: Lagomorpha; Rodentia; Soricomorpha; Carnivora; Chiroptera; shrews; moles; voles; lemmings; mice; bats; hares; weasels; lower jaw; skull; dentary; eastern Canada

\section{Introduction}

Small mammals consumed by predators are particularly difficult to identify because their skulls are often physically damaged or they have been degraded by gastric acids (Mayhew 1977). Cranial bones that resist degradation often disassociate from the larger component they were affixed to and are often found scattered in predator scats, pellets, or nests (Buidin et al. 2007; Khalafalla and Iudica 2010). They may also be found as concentrations of loose bones near caves or other shelters used by predators (Buden 1974). Predators such as mustelids have "food caches" in which they store carcasses for later consumption (Oksanen et al. 1985). As a result, prey remains may be disassociated and may accumulate.

Several published keys to small mammal skulls are based on the assumption that the whole skull is available (van Zyll de Jong 1983; Glass and Thies 1997; Lupien 2001, 2002; Nagorsen 2002; Chapman et al. 2007), but this is rarely the case with prey remains (Mollhagen et al. 1972; Buden 1974; Balciauskiene et al. 2002). Furthermore, loose bones of different individual prey items are often mixed. The minimum number of individuals is a derived unit of abundance often used in paleozoology (Lyman 2008). By using a single skull component, this method avoids overestimating species abundance in bone aggregations. The mandible has been proposed as a useful cranial component for identifying groups of mammals (Roest 1991; Balciauskiene et al. 2002), but it has rarely been used to identify mammals to the species level, except for shrews (Repenning 1967; Carraway 1995).

The mandible, or lower jaw, is composed of teeth and a pair of dentary bones (Figure 1). The teeth of the mandible are often referred to as the lower dentition, and each tooth is identified with a lower case letter (i.e., p3 for the third premolar). For the present article, we focused on the mandible and thus omitted the term "lower". Because the left and right dentary often separate as a result of degradation, it is imperative that the same dentary bone (i.e., left or right, but not both) be used for counting purposes. 
Several diagnostic characters make the mandible an ideal tool for identifying most mammalian species that have very few but sturdy bones. The size, the dental formulae, and the occlusal patterns of the molar enamel are key characteristics that are often used in keys to skulls (Repenning 1967; Glass and Thies 1997; Lupien 2002; Nagorsen 2002). Furthermore, diagnostic characters of the dentary bones are found on both the anterior and the posterior parts. The size and shape of the lower edge of the ramus and the position of the mental and dental foramina, as well as the size and shape of the condylar, coronoid, and angular processes, are useful characters requiring only a few metric measurements (Roest 1991; Carraway 1995).

We present an identification key to the mandibles of all established small mammals (mean mass of $<5 \mathrm{~kg}$ ) of eastern Canada to assist in the identification of prey remains and other types of loose bones when skulls are incomplete or damaged. Each criterion mentioned in the couplets of the key is illustrated by a picture as a visual support. A glossary and the general nomenclature are also provided.

\section{Methods}

According to Merritt (2010), mammals may be categorized as small when the average mass of the species is less than $5 \mathrm{~kg}$. Based on this criterion, we selected all the small mammals established in the provinces of Ontario, Quebec, Newfoundland and Labrador, Prince Edward Island, New Brunswick, and Nova Scotia (Peterson 1966; Banfield 1974; Dobbyn 1994; Desrosiers et al. 2002; Naughton 2012). The general taxonomy used in the key is listed in Table 1.

This key summarizes all diagnostic mandible characters that we have found in the literature for the orders Lagomorpha (Roest 1991), Rodentia (Klingener 1963; Phillips and Oxberry 1972; Grayson et al. 1990; Roest 1991; Lupien 2002; Chapman et al. 2007), Soricomorpha (Hallet 1978; Yates and Schmidly 1978; van Zyll de Jong 1983; Carraway 1995; Glass and Thies 1997; Lupien 2001), Carnivora (Roest 1991; Glass and Thies 1997), and Chiroptera (Gaudin et al. 2011). Cer- tain species were very difficult to distinguish using the morphologic features of the mandible alone. Therefore, we included morphometric measurements such as the length of the mandible, the length of the mandibular tooth row, and the height of the coronoid process when two species or groups of species could be distinguished only by size.

We validated the mandible characteristics presented in this key by studying specimens from Ontario, Quebec, Newfoundland and Labrador, Prince Edward Island, New Brunswick, and Nova Scotia preserved in the Canadian Museum of Nature and Université Laval. Morphometric measurements were validated on 10 specimens of each species when possible. Otherwise, all specimens available were used. We further extracted a sample of reference mandibles from complete frozen specimens, in collaboration with the Ministère du Développement durable, de l'Environnement, de la Faune et des Parcs du Québec and the Université du Québec à Rimouski, and from specimens trapped during a related study (Fauteux et al. 2012). The relevance of the diagnostic characters in identifying prey remains was validated by Séguy (2010) using nest remains to quantify the diet of Northern Saw-whet Owls (Aegolius acadicus).

\section{Results and Discussion}

We found that 55 of the 60 small mammal species of eastern Canada could be identified from their mandibles. The White-footed Mouse (Peromyscus leuco$p u s$ ) and the Deer Mouse (P. maniculatus) could not be identified to the species level, because their mandibles are identical. Although both Peromyscus species may be differentiated using several skull measurements, biochemical and genetic markers are probably the only reliable methods to date (Aquadro and Patton 1980; Rich et al. 1996). Similarly, three species of lagomorphs (i.e., Lepus arcticus, L. europaeus, and L. townsendii) could not be distinguished using the mandibles alone.

Consulting species' distribution may facilitate identification of small mammals (Banfield 1974; Desrosiers et al. 2002; Naughton 2012). For example, Sciurus

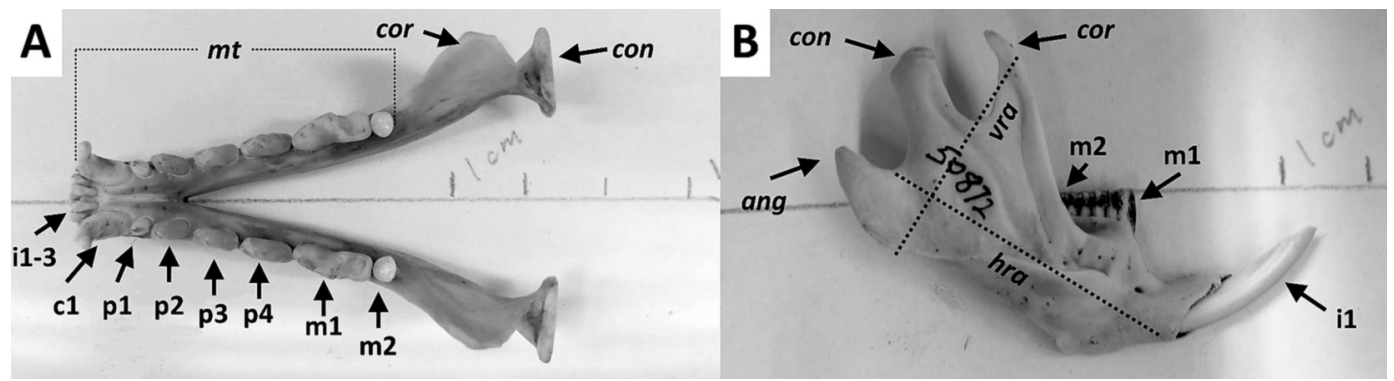

Figure 1. (A. Labial view; B. Occlusal view) The mandibles of carnivores (Martes americana) (A) and rodents (Ondatra zibethicus) (B). Labels refer to the incisor (i), canine (c), premolar (p), molar (m), mandibular tooth row ( $m t)$, coronoid process (cor), condyle (con), angular process (ang), vertical ramus ( $\mathrm{rra}$ ), and horizontal ramus ( $\mathrm{rra}$ ). 


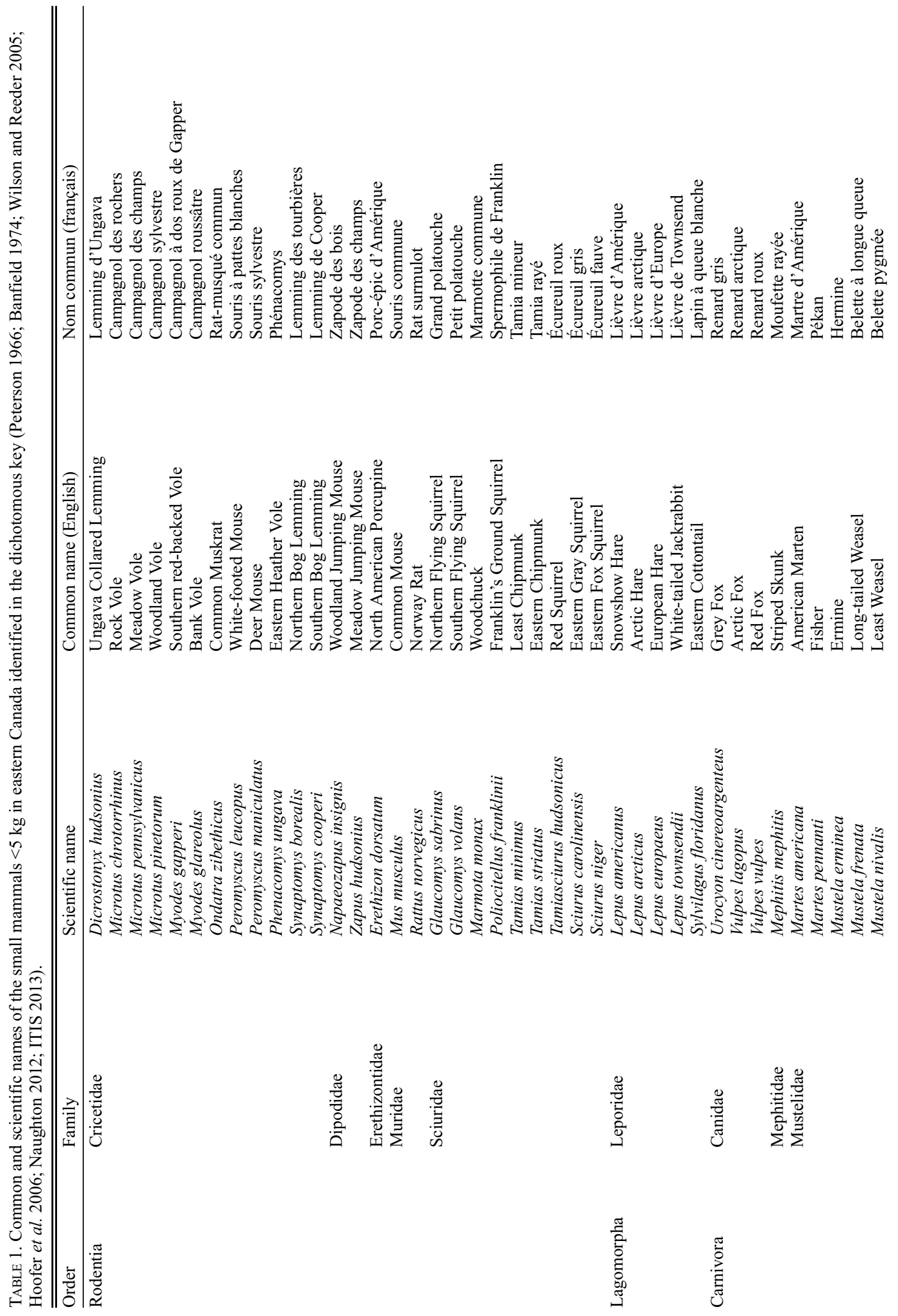




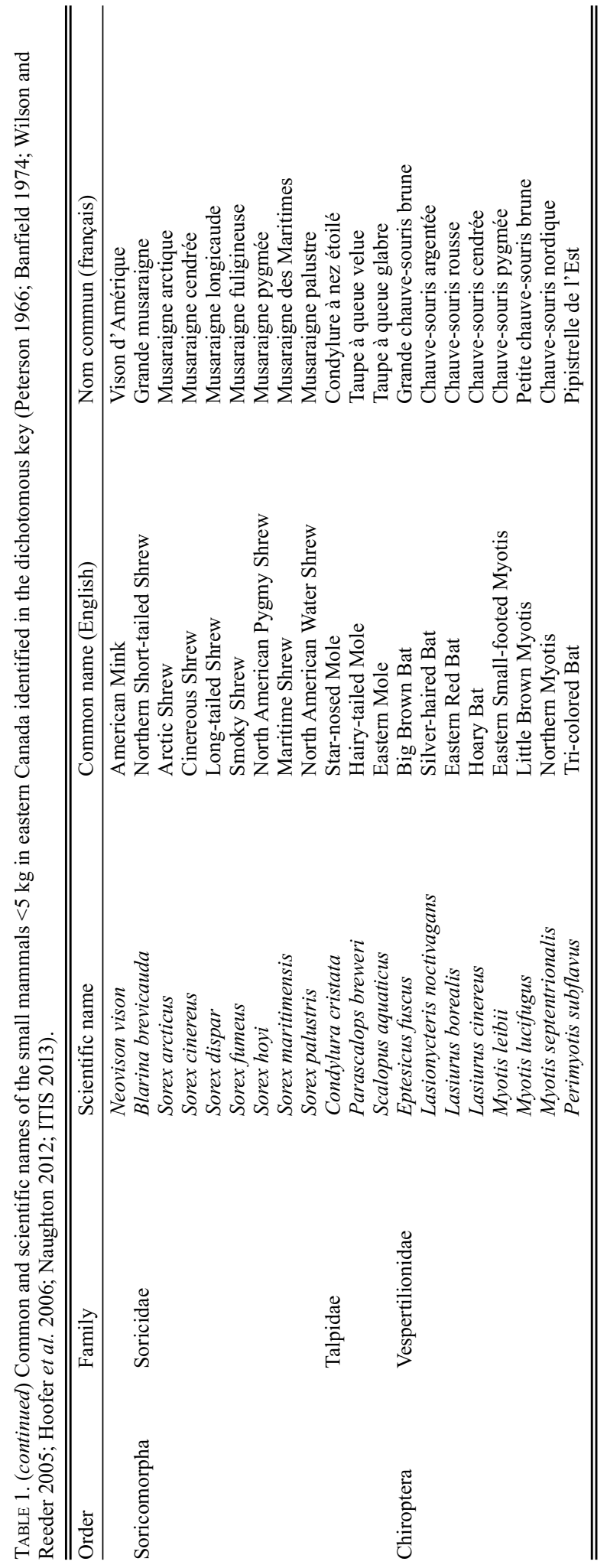


niger are found only in extreme southern Ontario, and the distribution of Sorex maritimensis is restricted to New Brunswick and Nova Scotia.

The mandible is highly polymorphic between and within orders. The order Soricomorpha can be distinguished from other orders because the canine is similar in size to the premolars and the angular process is long and slender (Figure 2B) (key section D). In Lagomorpha, the large angular process and the very small coronoid process are probably the most distinctive characters (Figure 3A) (key section B). In contrast, species of the order Rodentia have a well-developed coronoid process, often with complex occlusal patterns on the molars (Figures 3B) (key section C). Carnivores have large canines and a coronoid process that is disproportionately larger than the condyle and the angular process (Figure 4B) (key section E). Species from the order
Chiroptera are mainly characterized by the relatively small vertical ramus and the conspicuous bump on the lower edge of the horizontal ramus beneath the canine (Figure 5B) (key section F).

In some cases, mandibles may be broken and/or teeth may be missing. To address this problem, we provide two or more criteria. However, we struggled to find more than one mandibular characteristic in certain groups of species. In the orders Lagomorpha and Carnivora, only the length of the mandibular tooth row and the height of the coronoid process may be used effectively to distinguish the hares (Lepus spp.) and the weasels (Mustela spp.). Voles and lemmings may be more effectively differentiated with dental criteria, and identifications may become difficult when the teeth are missing (Banfield 1974; Lupien 2002). Although identifications using heavily degraded mandibles (e.g.,

\section{A}

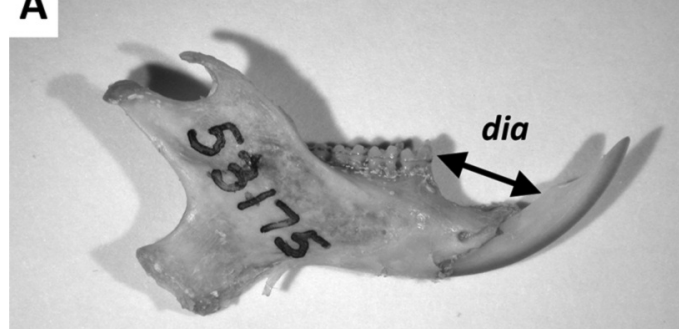

B

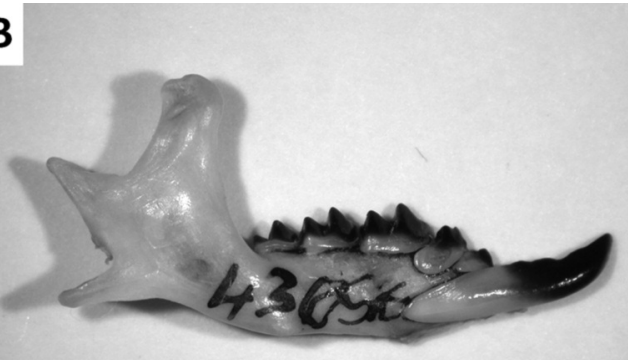

FIGURE 2. (labial view) Dentary bone of rodents with a large diastema (dia) (Glaucomys volans) (A), and soricomorphs (Blarina brevicauda) (B).

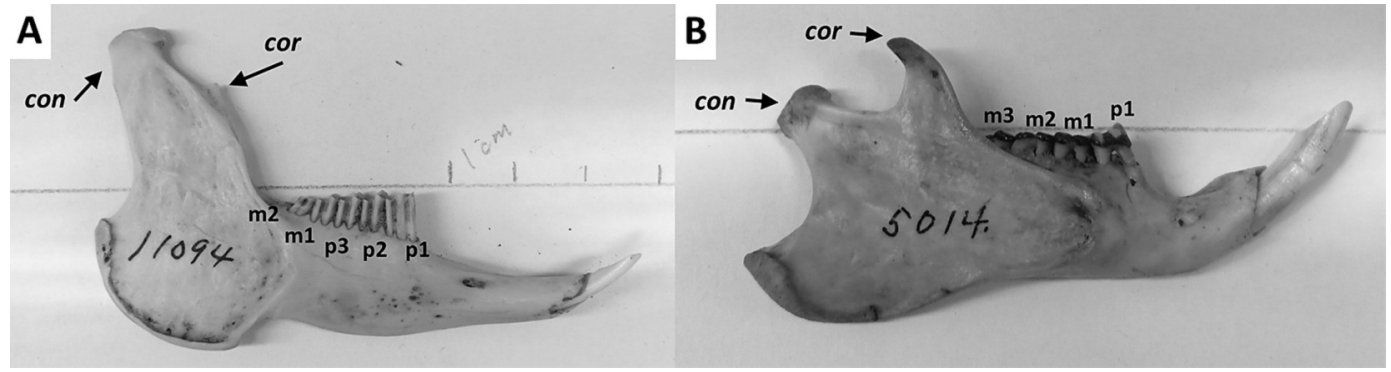

FiguRE 3. (labial view) Coronoid process (cor) and condyle (con) of lagomorphs (Lepus arcticus) (A) and rodents (Marmota $\operatorname{monax})(\mathrm{B})$.
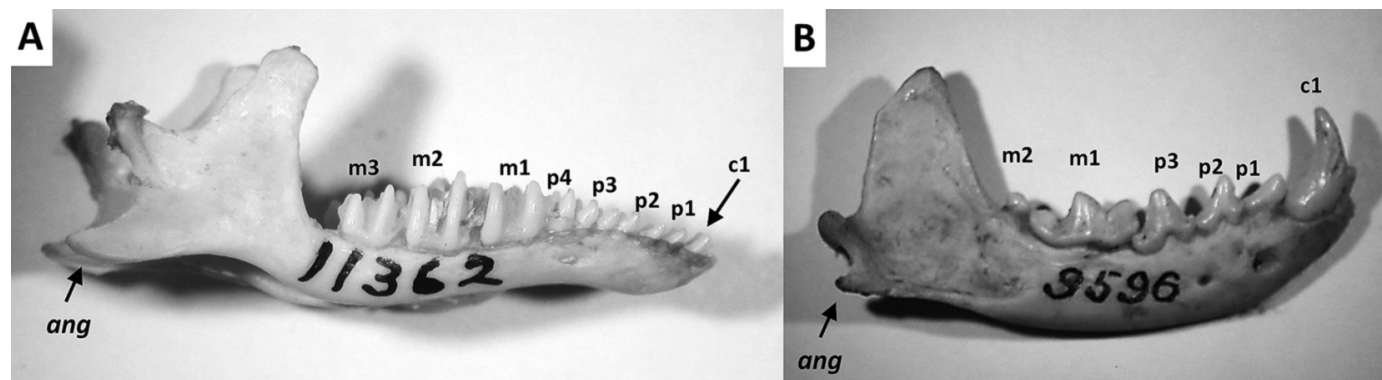

FIGURE 4. (labial view) Size of the angular process as well as the size of the canine compared to the adjacent premolar in soricomorphs (Parascalops breweri) (A) and carnivores (Neovison vison) (B). 


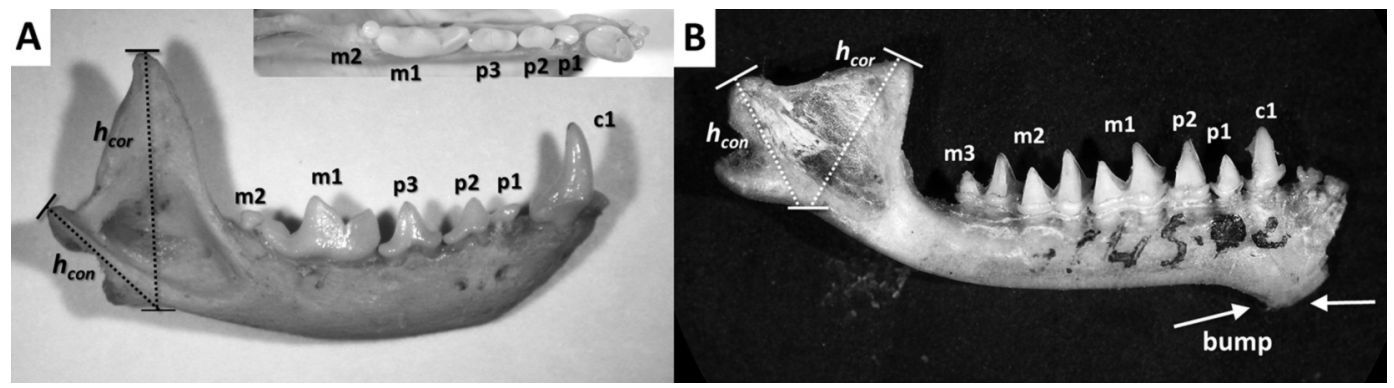

FIGURE 5. (labial view) Dentary bones of carnivores (Mustela erminea) (A) and chiropterans (Perimyotis subflavus) (B) with the height of the condyle $\left(h_{c o n}\right)$, height of the coronoid process $\left(h_{c o r}\right)$, and the conspicuous mandibular bump of chiropterans.

complete absence of teeth on specimens of Cricetidae) may be generalized, the resistance of mandibles to degradation and the number of criteria we included in the key should prove useful in identifying lightly degraded mandibles to the species level.

Sex and age are important factors that may mean that certain mandible criteria may not be useful (because of sexual dimorphism and growth). We acknowledge that this may be a limitation to a key based on osteometry. Identifications conducted on bones of juveniles that are mixed with bones of adult prey may have a lower resolution (i.e., identifications stop at the genus level) than when only adults are present. As a solution, we included in the vast majority of couplets one or more known morphologic characters that are persistent through age and that do not differ between males and females, such as the morphology of the ramus. Using the mandible is also a useful tool for the counting of individual remains and do not necessitate lengthy and costly methods that often require advanced laboratory skills (e.g., identifications using DNA).

This is a new tool for identifying and monitoring all of the small mammals of eastern Canada. To our knowledge, this is the first comprehensive key designed in North America that uses the mandible exclusively. Use of the mandible enables degraded specimens of most small mammals to be identified down to the species level and it facilitates counting activities. Moreover, bats of the genera Myotis, Perimyotis, and Eptesicus have declined dramatically in the past few years as a result of the spread of white-nose syndrome (caused by Pseudogymnoascus destructans) in the eastern part of the United States and Canada (Blehert et al. 2009). Identifying mandibles on the floor of caves and in other hibernacula might be useful for monitoring carcasses.

\section{Acknowledgements}

Financial support was provided by the Natural Sciences and Engineering Research Council of Canada (NSERC) and the Fonds de recherche du Québec Nature et technologies (FRQNT) of Quebec. We thank the Centre for Forest Research and the Conseil de re- cherches en sciences naturelles et en génie du Canada - Université du Québec en Abitibi-TémiscamingueUniversité du Québec à Montréal (CRSNG-UQATUQAM) Industrial Chair in Sustainable Forest Management for technical support. We thank the Canadian Museum of Nature and Michel Gosselin and Kamal Khidas (both of the Canadian Museum of Nature) for their help with the skull collection and for providing us with a digital camera attached to a binocular. We thank David W. Nagorsen for providing constructive comments on earlier versions of the manuscript. We thank Amélie Drolet for linguistic revision of the text. We also thank all field assistants who participated in the collection of bones and the small mammal trapping campaigns.

\section{Literature Cited}

Aquadro, C. F., and J. C. Patton. 1980. Salivary amylase variation in Peromyscus: use in species identification. Journal of Mammalogy 61: 703-707.

Balciauskiene, L., R. Juskaitis, and R. Mazeikyte. 2002. Identification of shrews and rodents from skull remains according to the length of a tooth row. Acta Zoologica Lituanica 12: 353-361.

Banfield, A. W. F. 1974. The mammals of Canada. University of Toronto Press, Toronto, Ontario, for the National Museum of Natural Sciences, National Museums of Canada. 438 pages.

Blehert, D. S., A. C. Hicks, M. Behr, C. U. Meteyer, B. M. Berlowski-Zier, E. L. Buckles, J. T. H. Coleman, S. R. Darling, A. Gargas, R. Niver, J. C. Okoniewski, R. J. Rudd, and W. B. Stone. 2009. Bat white-nose syndrome: an emerging fungal pathogen? Science 323: 227.

Buden, D. W. 1974. Prey remains of Barn Owls in the southern Bahama Islands. Wilson Bulletin 86: 336-343.

Buidin, C., Y. Rochepault, and J. P. L. Savard. 2007. Régime alimentaire de la Nyctale de Tengmalm en Minganie durant la nidification. Naturaliste canadien 131: 28-33.

Carraway, L. N. 1995. A key to recent Soricidae of western United States and Canada based primarily on dentaries. Museum of Natural History, University of Kansas, Lawrence, Kansas. 48 pages.

Chapman, B. R., S. B. Castleberry, and J. Laerm. 2007. Dichotomous keys to the mammals of the South by order. Pages 35-56 in The Land Manager's Guide to Mammals of the South. Edited by M. K. Trani, W. M. Ford, and B. R. 
Chapman. USDA Forest Service and the Nature Conservancy, Durham, North Carolina.

Desrosiers, N., R. Morin, and J. Jutras. 2002. Atlas des micromammifères du Québec. Société de la faune et des parcs du Québec, Quebec City, Quebec. 92 pages.

Dobbyn, J. S. 1994. Atlas of the Mammals of Ontario. Federation of Ontario Naturalists, Don Mills, Ontario. 120 pages.

Fauteux, D., L. Imbeau, P. Drapeau, and M. J. Mazerolle. 2012. Small mammal responses to coarse woody debris distribution at different spatial scales in managed and unmanaged boreal forests. Forest Ecology and Management 266: 194-205.

Gaudin, T. J., A. N. Miller, J. L. Bramblett, and T. P. Wilson. 2011. Holocene and late Pleistocene bat fossils (Mammalia: Chiroptera) from Hamilton County, TN, and their ecological implications. Southeastern Naturalist 10: 609-628.

Glass, B. P., and M. L. Thies. 1997. A Key to the Skulls of North American Mammals. Third edition. Sam Houston State University, Hunstville, Texas. 97 pages.

Grayson, D. K., C. Maser, and Z. Maser. 1990. Enamel thickness of rooted and rootless microtine molars. Canadian Journal of Zoology 68: 1315-1317.

Hallet, J. G. 1978. Parascalops breweri. Mammalian Species 98: $1-4$.

Hoofer, S. R., R. A. V. D. Bussche, and I. Horáček. 2006. Generic status of the American pipistrelles (Vespertilionidae) with description of a new genus. Journal of Mammalogy 87: 981-992.

ITIS. 2013. Integrated Taxonomic Information System. U.S. Geological Survey. http://www.itis.gov. (Accessed 27 October 2013).

Khalafalla, S. M., and C. A. Iudica. 2010. Barn and LongEared Owl diets: a comparative study from central Pennsylvania and a key for identification of prey items. Northeastern Naturalist 17: 147-154.

Klingener, D. 1963. Dental evolution of Zapus. Journal of Mammalogy 44: 248-260.

Lupien, G. 2001. Recueil photographique des caractéristiques morphologiques servant à l'identification des micromammifères du Québec: volume I - insectivores. Société de la Faune et des Parcs du Québec, Jonquière, Québec. 23 pages.

Lupien, G. 2002. Recueil photographique des caractéristiques morphologiques servant à l'identification des micromammifères du Québec: volume II - rongeurs. Société de la Faune et des Parcs du Québec, Jonquière, Québec. 26 pages.

Lyman, R. L. 2008. Quantitative paleozoology. Cambridge University Press, New York, New York. 372 pages.
Mayhew, D. F. 1977. Avian predators as accumulators of fossil mammal material. Boreas 6: 25-31.

Merritt, J. F. 2010. The Biology of Small Mammals. Johns Hopkins University Press, Baltimore, Maryland. 313 pages.

Mollhagen, T. R., R. W. Wiley, and R. L. Packard. 1972. Prey remains in Golden Eagle nests: Texas and New Mexico. Journal of Wildlife Management 36: 784-792.

Nagorsen, D. W. 2002. An Identification Manual to the Small Mammals of British Columbia. British Columbia Ministry of Sustainable Resource Management, Victoria, British Columbia. 153 pages.

Naughton, D. 2012. The Natural History of Canadian Mammals. Canadian Museum of Nature, Ottawa, Ontario, and University of Toronto Press, Toronto, Ontario. 824 pages.

Oksanen, T., L. Oksanen, and S. D. Fretwell. 1985. Surplus killing in the hunting strategy of small predators. American Naturalist 126: 328-346.

Peterson, R. L. 1966. The Mammals of Eastern Canada. Oxford University Press, Toronto, Ontario. 465 pages.

Phillips, C. J., and B. Oxberry. 1972. Comparative histology of molar dentitions of Microtus and Clethrionomys, with comments on dental evolution in microtine rodents. Journal of Mammalogy 53: 1-20.

Repenning, C. A. 1967. Subfamilies and Genera of the Soricidae. United States Department of the Interior, Washington, D.C. 74 pages.

Rich, S. M., C. W. Kilpatrick, J. L. Shippee, and K. L. Crowell. 1996. Morphological differentiation and identification of Peromyscus leucopus and P. maniculatus in Northeastern North America. Journal of Mammalogy 77: 985-991.

Roest, A. I. 1991. Key-Guide to Mammal Skulls and Lower Jaws. Mad River Press, Eureka, California. 39 pages.

Séguy, M. 2010. Les habitudes alimentaires de la petite nyctale (Aegolius acadicus) en sapinière à bouleau blanc du Québec. Master's thesis, Université Paul Cézanne, Marseille, France.

van Zyll de Jong, C. G. 1983. Traité des mammifères du Canada. 1. Les marsupiaux et les insectivores. Musée national des sciences naturelles, Ottawa, Ontario. 217 pages.

Wilson, D. E., and D. M. Reeder. 2005. Mammal Species of the World. Third edition. http://vertebrates.si.edu/msw /mswCFApp/msw/index.cfm. (Accessed 27 October 2013).

Yates, T. L., and D. J. Schmidly. 1978. Scalopus aquaticus. Mammalian Species 105: 1-4.

Supplementary material available at:

http://www.canadianfieldnaturalist.ca

Received 9 January 2013

Accepted 8 April 2013 


\section{Glossary of terms}

Alveolus

Angular process

Anteroconid

Anteromedian fold

Anteroposterior length

Brachydont tooth

Condyle/condylar process

\section{Coronoid process}

Closed triangle (of enamel)

Mandibular foramen

Dentary bone

Diastema (plural: diastemata)

Enamel

Horizontal ramus

Hypoconid

Hypsodont tooth

Interdenticular space

Labial

Labiolingual width

Length of the mandibular tooth row

Lingual

Mandible

Mandibular tooth row

Mental foramen

Metaconid

Occlusal

Paraconid

Pigmentation

Postmandibular foramen

Premetaconid fold

Protoconid

Re-entrant angles

Temporal fossa

Vertical ramus
Socket in which the roots of a tooth are set (Figures 24, 25, and 28) (alv). Posterior and ventral-most bony projection of the mandible; the angular process is posterior to the coronoid process (Figures 1 and 24) (ang). Anterior-most cusp on the $\mathrm{m} 1$ of jumping mice (Figure 19) (antc).

Concave fold created by the anteroconid on the anterior part of $\mathrm{m} 1$ (antf). Length in the direction of the mandibular tooth row.

Closed-rooted tooth with determinate growth (Figures 22 and 23).

Bony projection located on the ramus between the coronoid and the angular process (Figures 1 and 24) (con).

Posterior and dorsal-most bony projection of the mandible; the coronoid process is anterior to the angular process (Figures 1 and 24) (cor).

In rodents, the external layer of molars that forms occlusal triangular shapes (Figures 16 and 21) (ct).

Small hole located below the temporal fossa and serves as a canal for the dental nerve.

One side (half) of the mandible.

Space between two adjacent teeth (Figure 2) (dia).

The hard external layer of the tooth.

The anterior part of the dentary that supports the teeth (Figure 1B) ( $h r a)$. The most posterior cusp (Figure 24).

Continually growing tooth. The enamel typically covers most of the tooth. Teeth are rootless (Figures 22 and 23).

Space between the cusps present on the incisors of shrews (Figure 30). Next to the lips.

Length of teeth in the direction perpendicular to the mandibular tooth row.

Length of the lower tooth row (c1-m3) (Figures 1, 6, 33, 37, and 42).

Next to the tongue; the interior of the mouth.

Both dentary bones, often referred as the lower jaw ( $m a)$.

All contiguous teeth of one dentary bone $(m t)$. In Carnivora, Chiroptera, and Soricimorpha, all teeth form the toothrow. In Rodentia and Lagomorpha, premolars and molars form the toothrow.

Small hole located on the labial face of the horizontal ramus (Figure 24). Cusp posterior to the anteroconid on the lingual side of $\mathrm{m} 1$ in jumping mice.

The side of the teeth which meets with the opposing teeth.

Anterior-most cusp on molars in lateral view (Figure 24).

Coloration of the teeth $(p g)$. It is often dark in shrews.

Small hole next to the mandibular foramen that connects with the temporal fossa (Figure 30).

Small depression, resembling a trench, separating the anteroconid from the metaconid on the molars of jumping mice (Figure 19) (prmf).

Middle cusp on the molars of shrews in lateral view (Figures 19 and 24).

Inward pointing angle defined by the margin of the prismatic molars in voles (Figures 16 and 21) ( $\mathrm{ra}$ ).

Large opening on the lingual side of the vertical ramus.

The posterior part of the dentary, composed of the coronoid, condylar, and angular processes (Figure 1B) (vra). 


\section{Key to the mandibles of small mammals of eastern Canada \\ (full key illustrated with pictures provided in Supplementary material available at: http://www.canadianfield naturalist.ca)}

\section{A. General key to small mammals}



1b. No diastema between the incisor and molars (Figure 2B)

2a. Two premolars and three molars; coronoid process and condylar process not differentiated or coronoid process minute (Figure $3 \mathrm{~A}) \quad \ldots \ldots \ldots \ldots \ldots \ldots \ldots \ldots \ldots \ldots \ldots \ldots \ldots \ldots$ Lagomorpha (section B) $2 \mathrm{~b}$. One premolar or none and three molars; coronoid process clearly differentiated from the condylar

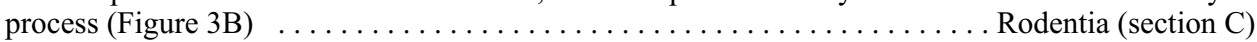

3a. Canines and premolars similar in size; well-developed angular process that is often the most posterior part of the dentary bone (Figure $4 \mathrm{~A}) \ldots \ldots \ldots \ldots \ldots \ldots$. Soricomorpha (section D) 3b. Canines two to three times the size of the adjacent premolar; small but robust angular process

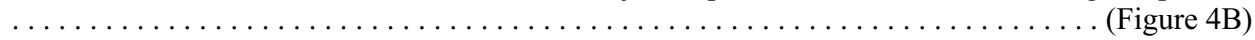

4a. The most posterior molar often much smaller than the most anterior molar; lower edge of ramus without a bump under the canine; height of the coronoid process much higher than the height of the

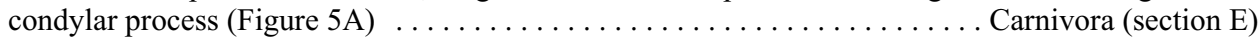
4b. Three W-shaped molars of similar size; lower edge of ramus with a bump under the canine; height of the coronoid process similar in size to or slightly higher than the height of the condylar process (Figure 5B)

\section{B. Lagomorpha (Leporidae)}

5a. Height of coronoid process $>40 \mathrm{~mm}$; length of mandibular tooth row $>16 \mathrm{~mm}$ (Figure $6 \mathrm{~A}$ )

...................................... Lepus arcticus, L. townsendii, L. europaeus

5b. Height of coronoid process $<40 \mathrm{~mm}$; length of mandibular tooth row $<16 \mathrm{~mm}$ (Figure 6B) $\ldots$.

6a. Mental foramen easily visible from the occlusal view (Figure 7A)

6b. Mental foramen barely visible from the occlusal view (Figure $7 \mathrm{~B}$ ) Sylvilagus floridanus

6h. Mental foramen barely visible from the occlusal view (Figure $7 \mathrm{~B})$ Lepus americanus

\section{Rodentia (Cricetidae, Dipodidae, Erethizontidae, Muridae, and Sciuridae)}

7a. Lower edge of horizontal ramus with sharp angle under p1 (Figure 8A); angular process clearly smaller than the coronoid process; cheek teeth with closed circular patterns of enamel (Figure 8B)

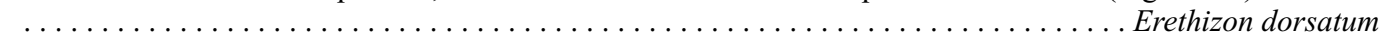

7b. Lower edge of horizontal ramus smooth; the coronoid process and the angular process are similar in size or the angular process is larger than the coronoid process; cheek teeth with triangular patterns

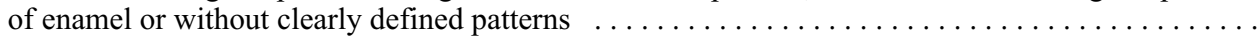

8a. Angular process clearly the most exterior part of the mandible (Figure 9A); angular process about twice as wide labially as the condylar process (Figure 9A); anterior edge of the coronoid process that connects with the angular process creates a bump pointing outwards at the level of $\mathrm{p} 1-\mathrm{m} 1$ in the

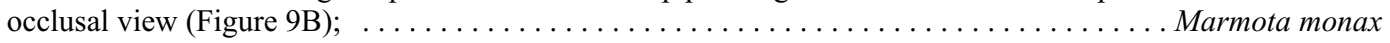
$8 \mathrm{~b}$. The condylar process or the coronoid process is the most exterior part of the mandible (occlusal view); no bumps created by the edge of the coronoid and angular processes next to $\mathrm{p} 1-\mathrm{m} 1$; angular process about the same labial thickness or less than the condylar process $\ldots \ldots \ldots \ldots \ldots \ldots$.

9a. Tip of the angular process clearly higher than the teeth (Figure 10A) . . . . . . . Ondatra zibethicus

9b. Tip of the angular process below or even with the teeth (Figure 10B)

10a. One premolar (Figure 11A); angular process extends slightly behind the coronoid process (Figure

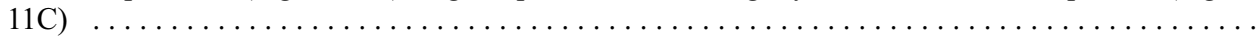
10b. No premolar (Figure 11B); angular process extends well behind the coronoid process (Figure 11D) 
11a. Coronoid process long; size of the notch between the coronoid and condylar processes similar in size to the notch between the condylar and angular processes (Figures 12A and 12B) $\ldots \ldots \ldots$ $11 \mathrm{~b}$. Coronoid process relatively short; size of the notch between the coronoid and condylar processes clearly smaller than the notch between the condylar and angular processes (Figures 12C and 12D) . .

12a. T-shaped condylar process; angular and condylar processes equally posterior (Figure 12A)

12 b. A-shaped condylar process; condylar process clearly the most posterior component of the ramus

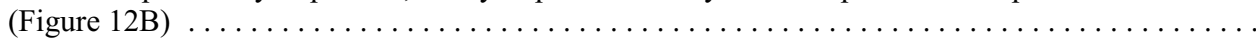

13a. Length of the mandibular tooth row $<5.5 \mathrm{~mm}$

Tamias minimus

13b. Length of the mandibular toothrow $>5.5 \mathrm{~mm}$

Tamias striatus

14a. Height of the coronoid process $>17 \mathrm{~mm}$; length of the mandibular tooth row $>35 \mathrm{~mm} \ldots \ldots$

14b. Height of the coronoid process $<17 \mathrm{~mm}$; length of the mandibular tooth row $<35 \mathrm{~mm}$

16

15a. Coronoid process short; notch created by the coronoid process and the condylar process appears wide open; lower tip of the angular process appears squared (Figure 13A) $\ldots \ldots \ldots \ldots \ldots$. Sciurus niger 15b. Coronoid process longer; coronoid notch narrow; lower tip of the angular process appears rounded



16a. Uppermost edge of the condylar process relatively flat (Figure 14A) . . . . . Tamiasciurus hudsonicus 16b. Uppermost edge of the condylar process concave (Figure 14B)

17a. Posterior tip of the angular process above the notch on the lower edge of the horizontal ramus (Figure 15A) Glaucomys volans

17b. Posterior tip of the angular process below or at the same level as the notch on the lower edge of the horizontal ramus (Figure 15B) Glaucomys sabrinus

18a. Molars without re-entrant angles or closed triangles (Figure 16A) $\ldots \ldots \ldots \ldots \ldots \ldots \ldots$

18b. Molars with well-defined lingual and labial re-entrant angles (Figure 16B), often with closed triangles

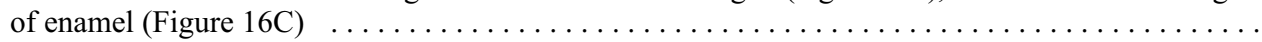

19a. Condylar process clearly the most posterior part of the dentary bone; coronoid process small, at about the same height as the condylar process (Figure 17A)

19b. Condylar process slightly posterior to the angular process or about equally posterior; coronoid process relatively long and higher than the condylar process (Figure 17B) $\ldots \ldots \ldots \ldots \ldots \ldots$

20a. Molars with complex patterns of enamel loops (Figure 18A) $\ldots \ldots \ldots \ldots \ldots \ldots \ldots \ldots$

20b. Molars with simple patterns of enamel loops (Figures 18B and 18C) $\ldots \ldots \ldots \ldots \ldots \ldots$

21a. Anteromedian fold present on $\mathrm{m} 1$; anteroconid of $\mathrm{m} 1$ clearly separated from the protoconid by the preprotoconid and premetaconid folds (Figure 19A) .................... Zapus hudsonius 21b. Anteromedian fold absent on $\mathrm{m} 1$; anteroconid of $\mathrm{m} 1$ not separated or slightly separated from the protoconid by the premetaconid fold (Figure 19B) .................... Napaeozapus insignis

22a. Molars with simple patterns of enamel (Figure 20A) . Mus musculus

$22 \mathrm{~b}$. Molars with two rows of cusps without patterns of enamel (Figure 20B) Rattus norvegicus

23a. Re-entrant angles of molars much deeper on lingual side than on labial side (Figures 21A, 21B,

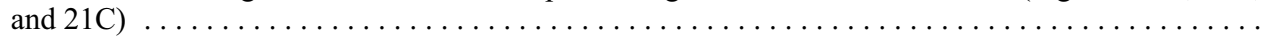
23b. Re-entrant angles of molars equal in size on both lingual and labial side (Figures 21D, 21E, 21F, $21 \mathrm{G}, 21 \mathrm{H}$, and 21I)

24a. Brachydont teeth (molars closed-rooted) (Figures 22A, 22B, 22C, 23A, and 23B); several small closed triangles on the labial side of molars (Figure 21A) $\ldots \ldots \ldots \ldots \ldots \ldots$. . . . . . . . . . 24b. Hypsodont teeth (molars open-rooted) (Figures 22D and 23C); one closed triangle or none on the labial side of each molar (Figures 21B and 21C) 
25a. A single closed triangle on the labial side of each molar (Figure 21B) . . . . . . Synaptomys cooperi 25b. No closed triangle on the labial side of molars (Figure 21C) Synaptomys borealis

26a. Brachydont teeth (molars closed-rooted) (Figures 22A, 22B, 22C, 23A, and 23B); occlusal triangles of molars rounded and "enclosed" by the enamel borders (Figures 21D and 21E) . . . . . . . . . 26b. Hypsodont teeth (molars open-rooted) (Figures 22D and 23C); occlusal closed triangles with sharp

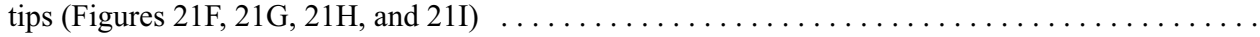

27a. Occlusal triangular shapes of enamel of $\mathrm{m} 1$ and $\mathrm{m} 2$ often connected by wide bridges; shape of the anterior triangle of $\mathrm{m} 3$ is typically similar to the posterior triangles (Figure 21D) . . ......Myodes gapperi $27 \mathrm{~b}$. Occlusal triangles on $\mathrm{m} 1$ and $\mathrm{m} 2$ often connected by narrow bridges; shape of the anterior triangle of $\mathrm{m} 3$ often different from the other triangles (Figure 21E) $\ldots \ldots \ldots \ldots \ldots \ldots$. . . . . . . .

28a. Presence of a small fold of enamel on the anterior and lingual side of $\mathrm{m} 2$ (Figure 21F)

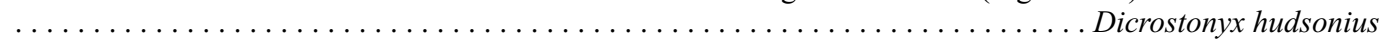
28b. Absence of a small fold of enamel on the anterior and lingual side of $\mathrm{m} 2$ (Figures $21 \mathrm{G}, 21 \mathrm{H}$,

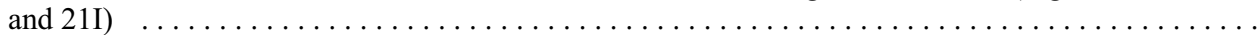

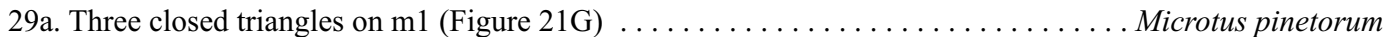
29b. Five closed triangles on $\mathrm{m} 1$ (Figures $21 \mathrm{H}$ and 21I)

30a. Two closed triangles on $\mathrm{m} 2$ (Figure $21 \mathrm{H})$ Microtus chrotorrhinus $30 \mathrm{~b}$. Four closed triangles on $\mathrm{m} 2$ (Figure 21I) Microtus pennsylvanicus

\section{Soricomorpha (Soricidae and Talpidae)}

31a. Teeth all white; incisors without a posterior cusp; alveolus of incisors does not extend under pre-

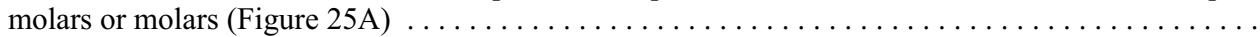
31b. Tip of teeth often with red and/or brown pigments; incisors with a posterior cusp; alveolus of incisors extends beneath the first premolar or posteriorly (Figures 24 and 25B) $\ldots \ldots \ldots \ldots \ldots$

32a. Two incisors, no canine, and three premolars; presence of a short diastema between the second incisor and the first premolar (Figure $26 \mathrm{~A}) \ldots \ldots \ldots \ldots \ldots \ldots \ldots \ldots \ldots \ldots \ldots \ldots \ldots$ Scalopus aquaticus $32 \mathrm{~b}$. Three incisors, one canine, and four premolars; presence of several short diastemata between the premolars (Figure 26B) or complete absence of diastemata (Figure 26C) $\ldots \ldots \ldots \ldots \ldots \ldots$.

33a. Canine and the first three premolars separated by short diastemata; angular process long and slender; condylar process about the same height as the coronoid process or higher; coronoid process clearly smaller than the condylar process (Figure $26 \mathrm{~B}) \ldots \ldots \ldots \ldots \ldots \ldots \ldots \ldots$ Condylura cristata 33b. Canine and first three premolars not separated by diastemata; coronoid process higher than the condylar process; coronoid larger than the condylar process (Figure 26C) . . . . . . Parascalops breweri

34a. Alveolus of incisor extends slightly or substantially beneath $\mathrm{m} 1$; alveolus extends at the level of

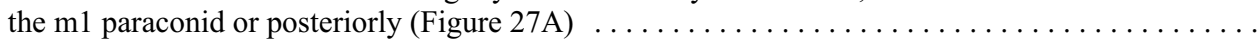
34b. Alveolus of incisor does not extend beneath the $\mathrm{m} 1$ paraconid (Figure 27B) $\ldots \ldots \ldots \ldots$.

$35 \mathrm{~b}$. Three small cusps on the occlusal surface of the incisor; angular process long and very slender

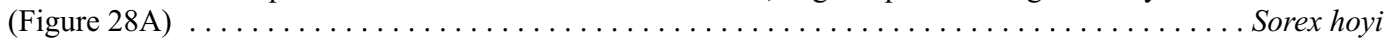
35a. One or two small cusps on the occlusal surface of the incisor; angular process relatively short and robust (Figure 28B) Blarina brevicauda

36a. Mental foramen located beneath the $\mathrm{m} 1$ paraconid; the space between both cusps on the molars

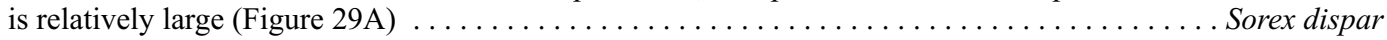
36b. Mental foramen located beneath the $\mathrm{m} 1$ protoconid or posteriorely; the space between both cusps

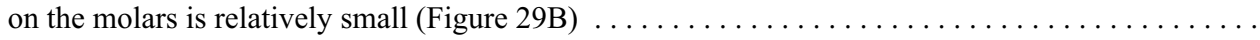


38a. Height of coronoid process $<4.5 \mathrm{~mm}$ (Figure 24) $\ldots \ldots \ldots \ldots \ldots \ldots \ldots$ Sorex maritimensis

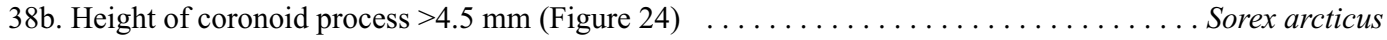

39a. Height of coronoid process $>4.5 \mathrm{~mm}$ (Figure 24$) \ldots \ldots \ldots \ldots \ldots \ldots \ldots \ldots \ldots \ldots \ldots \ldots$ Sorex palustris

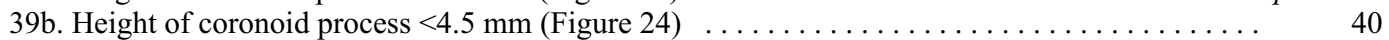

40a. Height of coronoid process $<3.75 \mathrm{~mm}$ (Figure 24$) \ldots \ldots \ldots \ldots \ldots \ldots \ldots \ldots \ldots \ldots$ Sorex cinereus

40b. Height of coronoid process $>3.75 \mathrm{~mm}$ (Figure 24) $\ldots \ldots \ldots \ldots \ldots \ldots \ldots \ldots \ldots$ Sorex fumeus

\section{E. Carnivora (Canidae, Mephitidae, and Mustelidae)}

41a. Two molars; very small to no diastema between $\mathrm{c} 1$ and $\mathrm{p} 1$; anterior part of the ramus under the

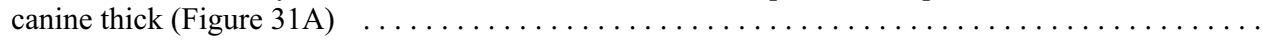
41b. Three molars; diastema between $\mathrm{c} 1$ and $\mathrm{p} 1$ about equal in size to $\mathrm{p} 1$ or larger; anterior part of the

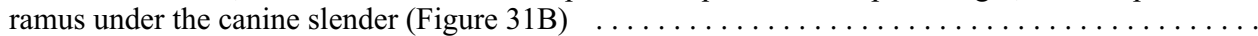

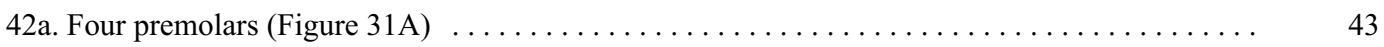

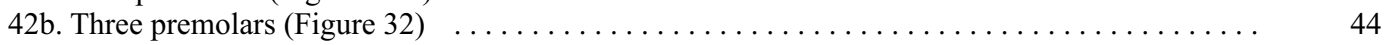

43a. Length of the mandibular tooth row $<38 \mathrm{~mm}$; posterior mental foramen located beneath the hypoconid of $\mathrm{p} 3$; coronoid process relatively sharp (Figure $33 \mathrm{~A}) \ldots \ldots \ldots \ldots$ Martes americana $43 \mathrm{~b}$. Length of the mandibular tooth row $>38 \mathrm{~mm}$; posterior mental foramen often located beneath the protoconid of $\mathrm{p} 3$; coronoid process rounded (Figure 33B) $\ldots \ldots \ldots \ldots \ldots \ldots \ldots$. . . . . . . pennanti

44a. Bump present on the anterior part of the horizontal ramus approximately beneath p1 (Figure 34A);

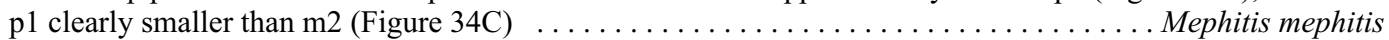
44b. Absence of a bump on the anterior part of the horizontal ramus (Figure 34B); p1 larger than $\mathrm{m} 2$ or

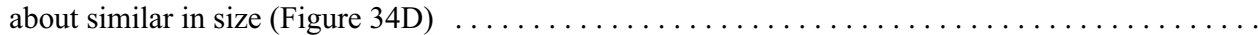

45a. p2 often with a well-developed paraconid (Figure 35A); posterior edge of the vertical ramus with a distinct convex notch between the coronoid process and the condylar process (Figure 36A)

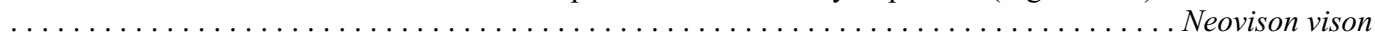
45b. p2 often without a small anterior cusp (Figure 35B); posterior edge of the vertical ramus straight between the coronoid process and the condylar process (Figure 36B) $\ldots \ldots \ldots \ldots \ldots \ldots \ldots$

46a. Height of coronoid process $<7.1 \mathrm{~mm}$; length of mandibular tooth row $<10 \mathrm{~mm}$ (Figure 37)

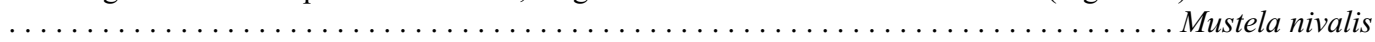

46b. Height of coronoid process $>7.1 \mathrm{~mm}$; length of mandibular tooth row $>10 \mathrm{~mm}$ (Figure 37) $\ldots$.

47a. Height of the coronoid process generally $<10.5 \mathrm{~mm}$; length of mandibular tooth row never $>16 \mathrm{~mm}$ (Figure 37); posterior edge of the vertical ramus between the coronoid process and the condylar process

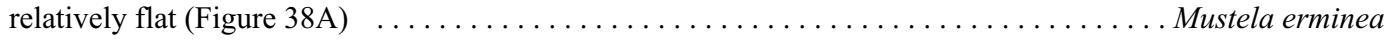
$47 \mathrm{~b}$. Height of the coronoid process generally $>10.5 \mathrm{~mm}$; length of mandibular tooth row often $>16 \mathrm{~mm}$ (Figure 37); posterior edge of the vertical ramus between the coronoid process and the condylar process

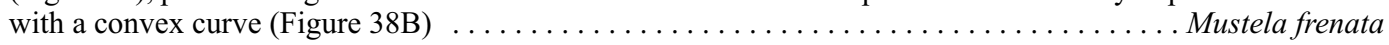

48a. Presence of a clearly defined step on the lower edge of the horizontal ramus anterior to the angular process; diastemata between $\mathrm{c} 1$ and $\mathrm{p} 1$, between $\mathrm{p} 1$ and $\mathrm{p} 2$, and between $\mathrm{p} 2$ and $\mathrm{p} 3$ (Figure

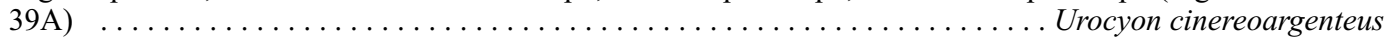
48b. Lower edge of the horizontal ramus anterior to the angular process smooth, without a step; only

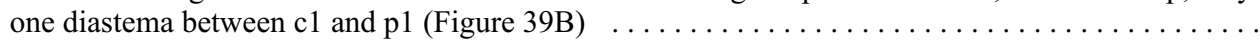

49a. Anteroposterior length of the diastema between $\mathrm{c} 1$ and $\mathrm{p} 1$ smaller than $\mathrm{p} 1$ (Figure 40A) ... Vulpes lagopus $49 \mathrm{~b}$. Anteroposterior length of the diastema between $\mathrm{c} 1$ and $\mathrm{p} 1$ about equal to $\mathrm{p} 1$ or larger (Figure 40B) 
51a. Mandibular length $>11.5 \mathrm{~mm}$ (Figure 42); hypoconid of $\mathrm{p} 3$ with lingual crest directed medially creating a distinct lingual bulge (Figure $43 \mathrm{~A}) \ldots \ldots \ldots \ldots \ldots \ldots \ldots$ Lasionycteris noctivagans 51b. Mandibular length $<11.5 \mathrm{~mm}$ (Figure 42); hypoconid of $\mathrm{p} 3$ without a distinct lingual bulge

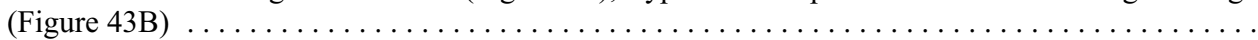

52a. p3 rectangular, anteroposterior length greater than labiolingual width (Figure 44A); mandibular length generally $\geq 11 \mathrm{~mm}$ (Figure 42$) \ldots \ldots \ldots \ldots \ldots \ldots \ldots \ldots \ldots \ldots \ldots \ldots \ldots \ldots \ldots \ldots \ldots \ldots \ldots$ My septentrionalis 52b. p3 squared, anteroposterior length approximately equal to labiolingual width (Figure 44B);

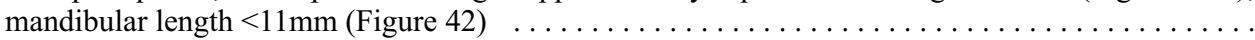

53a. Mandibular length generally $>10 \mathrm{~mm}$; length of the mandibular tooth row generally $>5.5 \mathrm{~mm}$

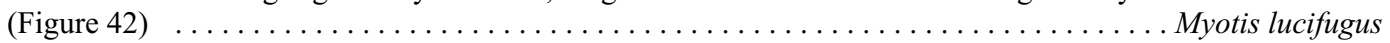
53b. Mandibular length generally $<10 \mathrm{~mm}$; length of the mandibular tooth row generally $<5.5 \mathrm{~mm}$

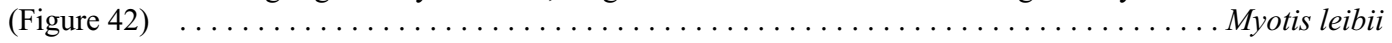

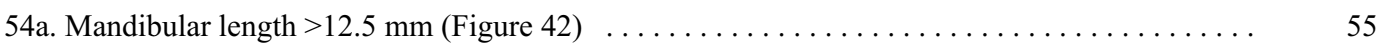

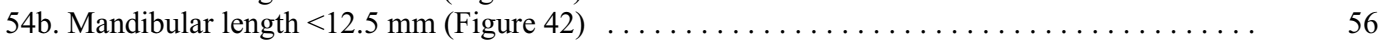

55a. Mandibular length $>14 \mathrm{~mm}$ (Figure 42); rounded coronoid process much taller than c1 (Figure 45A); p2 squared, with labiolingual width approximately equal to anteroposterior length (Figure 46A)

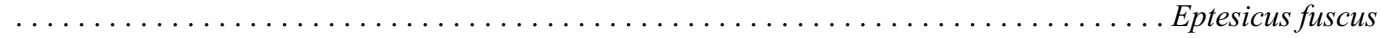
55b. Mandibular length $\leq 14 \mathrm{~mm}$ (Figure 42); sharp coronoid process approximately same height as $\mathrm{c} 1$ (Figure 45B); p2 rectangular with labiolingual width greater than anteroposterior length (Figure 46B)

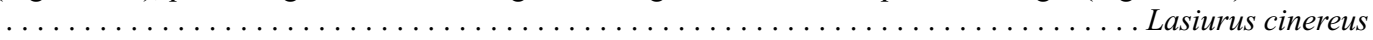

56a. Length of the mandibular tooth row $<5 \mathrm{~mm}$ (Figure 42); small diastemata separate i2 from i3, i3 from $\mathrm{c} 1$, and $\mathrm{p} 1$ from $\mathrm{p} 2$; $\mathrm{c} 1$ approximately same height as $\mathrm{p} 2$ (Figure 47A) ....... Perimyotis subflavus 56b. Length of the mandibular tooth row $>5 \mathrm{~mm}$ (Figure 42); no diastema between $\mathrm{i} 2$ and $\mathrm{i} 3$, i3 and $\mathrm{c} 1$, or $\mathrm{p} 1$ and $\mathrm{p} 2$; $\mathrm{c} 1$ taller than $\mathrm{p} 2$ (Figure $47 \mathrm{~B}) \ldots \ldots \ldots \ldots \ldots \ldots \ldots \ldots \ldots \ldots \ldots \ldots \ldots \ldots \ldots \ldots \ldots$ Lasiurus borealis 